УДК 316.6

DOI: https://doi.org/10.33120/ssj.vi46(49).164

\author{
Дишлова Наталія Володимирівна \\ кандидат психологічних наук, науковий співробітник \\ лабораторії психології малих груп та міжгрупових відносин, \\ Інститут соціальної та політичної психології НАПН України, \\ м. Київ, Україна \\ ORCID ID 0000-0002-8788-3111 \\ Dyshlova.Natalia@gmail.com
}

\title{
ОСОБЛИВОСТІ ПРОЖИВАННЯ ТА ДОЛАННЯ СКЛАДНИХ СОЩАЛЬНИХ СИТУАЦЙ УСИНОВЛЮВАЧАМИ В ГРУПОВІЙ ПСИХОЛОГІЧНІЙ РОБОТІ
}

Метою дослідження було визначити причини виникнення складних соціальних ситуацій у сім'ях усиновлювачів та особливості опрацювання таких ситуацій під час групової психологічної роботи. Для вирішення цих завдань використано напівструктуроване інтерв'ю, включене спостереження, методи і техніки транзактного аналізу та монодрами. Визначено, що складні соціальні ситуації в сім'ях усиновлювачів виникають найчастіше у батьків, які мають певні психологічні та соціально-психологічні особливості (неопрацьована власна дитяча травма, нерозв'язані проблеми в подружніх стосунках, неконструктивна мотивація до усиновлення; неспроможність оцінити свої слабкі та сильні сторони у вихованні дитинисироти або дитини, позбавленої батьківського піклування, яку вони хочуть усиновити або удочерити). На основі результатів опрацювання складних соціальних ситуацій 3 усиновлювачами в групі психологічної взаємодопомоги доведено ефективність групової психологічної роботи. Усиновлювачі опанували навички саморефлексії, почали самостійно аналізувати причини негативної поведінки дітей, навчилися відкрито говорити про власні переживання і страхи. Психологічна робота 3 батьківською і дитячою его-структурою методами транзактного аналізу та монодрами допомогла усиновлювачам прожити власні дитячі травми, що справило позитивний вплив на формування близьких стосунків 3 дитиною та вирішення складних соціальних ситуацій у сім'ї. У процесі групової роботи визначено низку групових механізмів, спираючись на які група усиновлювачів може розв'язувати проблеми сімейної взаємодії та долати складні соціальні ситуації. До таких механізмів віднесено групову фасилітацію, групову наративізацію індивідуальних історій, групову рефлексію та генераційний досвід долання травм. Показано, що завдяки цим механізмам та пов'язаним із ними груповим феноменам долаються соціальні та групові міфи про усиновлення як про подвиг і негативну фатальність ситуації усиновлення, відчуження та напруження в сім'ях, негативні сімейні сценарії взаємодії, трансгенераційні травми та негативні послання батьків, натомість набуваються нові моделі поведінки в сім'ї, розвиваються гармонійні стосунки. Перспективою подальшого дослідження $\epsilon$ корекція негативного життєвого сценарію усиновлених дітей шляхом групової психологічної роботи 3 ними починаючи з молодшого шкільного віку. Оскільки батьки не завжди можуть допомогти усиновленій дитині подолати психологічні проблеми самостійно, часто вони стикаються 3 негативною проєкцією і незаслуженим обезцінюванням та недовірою дітей. Практичне значення дослідження полягає в тому, що його результати можна використовувати для впровадження психологічного оцінювання майбутніх усиновлювачів. Створення психологічних груп взаємопідтримки усиновлювачів зменшує ризики дисфункції сім’ї та розусиновлення.

Ключові слова: усиновлювачі; складні соціальні ситуації; діти, позбавлені батьківського піклування; група взаємопідтримки; психологічна травма. 


\title{
FEATURES OF LIVING THROUGH AND OVERCOMING COMPLEX SOCIAL SITUATIONS BY ADOPTERS IN GROUP PSYCHOLOGICAL WORK
}

\author{
Nataliia V. Dyshlova \\ Ph.D. in Psychology, Research Associate, \\ Laboratory of Psychology of Small Groups and Intergroup Relations, \\ Institute for Social and Political Psychology, NAES of Ukraine, \\ Kyiv, Ukraine \\ ORCID ID 0000-0002-8788-3111 \\ Dyshlova.Natalia@gmail.com
}

The aim of the study is to determine the causes of complex social situations in the families of adoptive parents and the peculiarities of their processing in group psychological work. To solve these problems, it is used a semi-structured interview, included observations, methods, and techniques of transactional analysis and monodramas. It was determined that the emergence of complex social situations in the families of adoptive parents is characteristic of parents who have the following psychological and socio-psychological features: have unresolved own childhood trauma, unresolved marital problems, unconstructive motivation for adoption; lack of assessment of their weaknesses and strengths in the upbringing of an orphan or a child deprived of parental care whom they wish to adopt. The results of elaboration of difficult social situations with adoptive parents in the group of psychological mutual assistance proved the effectiveness of group psychological work with them. Psychological work of adoptive parents with parental and childish ego-structure by methods of transactional analysis and monodrama helps them to live their childhood traumas, which has a positive effect on the formation of close relationships with the child and solving difficult social situations in the family. In the process of group work, several group mechanisms were identified, based on which a group of adoptive parents solves problems of family interaction and overcomes difficult social situations. Such mechanisms include group facilitation, group narrativization of individual stories, group reflection, and generational experience of overcoming injuries. Through these mechanisms and related group phenomena, social and group myths about adoption as a feat and the negative fatality of the adoption situation, alienation, and tension in families, negative scenarios of family interaction, the trauma of generations and negative parental messages are overcome, as well as acquiring new patterns of behavior in the family and forming harmonious relationships. Prospects for further research are the correction of the negative life scenario of adopted children through group psychological work with them, starting from primary school age. Because parents cannot always help an adopted child overcome psychological problems on their own, they often face negative projection and undeserved devaluation and mistrust of children. The practical significance of the study is that its results can be used to introduce a psychological assessment of future adopters. Creating psychological support groups for adoptive parents reduces the risk of family dysfunction and adoption.

Keywords: adopters; difficult social situations; children deprived of parental care; mutual support group; psychological trauma.

Постановка проблеми. Сучасна національна система життєвлаштування дітей, позбавлених батьківського піклування, спрямована на зміну пріоритетів їхнього виховання 3 державних на сімейні форми виховання. 32017 року Урядом України розпочато реформу деінституалізації. Пріоритетною формою влаштування дітей визнано усиновлення. Водночас у 2018 році зафіксовано 21, а протягом 2019 року - 36 випадків скасування усиновлення. Сім'ї усиновлювачів тією чи іншою мірою стикаються з труднощами у взаємодії з дітьми, оскільки їхня поведінка зумовлена наслідками материнської депривації або негативного досвіду проживання в біологічній сім'ї. Проблема полягає в тому, що наразі немає системи психологічного оцінювання потенційних усиновлювачів, визначення їхніх слабких і сильних сторін. Разом з тим доведено, що поява дитини в сім'ї активізує у подружжя не тільки своєрідну активність “внутрішніх" батьків, а й переживання “внутрішньоі” дитини, яка може 
вступити в конкуренцію з реальною дитиною (Geissmann, \& Hauzel, 2000). Поява дитини провокує також відтворення власних дитячих травм батьків, які проєкуються на стосунки 3 усиновленою дитиною, що негативно впливає на психологічний мікроклімат у сім’і і може призводити до виникнення складних соціальних ситуацій: конфліктів 3 адміністрацією дитячих садків і шкіл, коли вихователі та вчителі оцінюють дитину як важкосоціалізовувану, скаржаться на ії поведінку, звинувачують батьків у поганому вихованні та просять перевести iii на домашню індивідуальну форму навчання; втечі дітей 3 дому; міжособових та міжгрупових конфліктів у соціальному полі взаємодії, коли конфлікти трапляються між усиновленою дитиною та іншими дітьми, що часто призводить до конфліктів між сім'ями або соціальної ізоляції усиновлювачів; бажання розусиновлення/розудочеріння дитини. Це призводить до напруженості в соціальній взаємодії між державними органами та інститутом сім'ї, що зазвичай зумовлює загострення проблемної ситуації усиновлювачів. Через відсутність соціально-психологічного супроводу сімей практично неможливо виявити початок дисфункції родини вже на ранніх стадіях та запобігти iї руйнуванню як у фактичному, так і психологічному сенсі. Тому актуальною темою дослідження $\epsilon$ визначення причин виникнення складних соціальних ситуацій усиновлювачів та психологічне опрацювання таких ситуацій шляхом усвідомлення усиновлювачами особливостей своєї батьківської ідентичності.

Аналіз останніх досліджень і публікацій. Розвиток дітей в умовах емоційної та соціальної депривації досліджували Я. Гошовський (2017), Н. Іванкова та М. Проселкова (2017), Л. Кремнєва (2017), Ю. Удовенко (2007). Аспектам соціально-психологічної адаптації дітей у сім'ях усиновлювачів приділяли увагу М. Майн (2014), Т. Мельничук (2013), Ю. Лахвіч (2017), О. Головньова (2017). Особливості розвитку та виховання дітей у заміщувальній сім’ї знайшли своє відображення у працях Г. Бевз (2015), Т. Демірджі (2016), I. Пєші (2003), Т. Отт (2016), І. Морозової (2016), К. Бєлогай (2016) та ін. Проте недостатньо розкритою досі залишається тема психологічної роботи з усиновлювачами, які опинилися в складній соціальній ситуації.

Метою статті $€$ визначення причин виникнення складних соціальних ситуацій у сім’ях усиновлювачів та особливостей їх долання в процесі групової психологічної роботи.

Виклад основного матеріалу дослідження. У наукових працях Е. Еріксона (1996) та Д. Віннікотта (2004) обстоюється думка, що в перші місяці після народження у дитини формується базове ставлення до світу: вона вирішує, чи заслуговує цей світ на довіру, чи він $\epsilon$ небезпечним. Головну роль у цьому відіграє ставлення значущого дорослого. Діти, позбавлені батьківського піклування, виховуються в неблагополучних сім'ях, що значно підвищує ризик формування у них негативного сценарію життя. Дослідження дітей, позбавлених батьківського піклування (Бардышевская, 2006; Прихожан, \& Толстых, 2007; Шпитц, 1946), показали, що порушення взаємодії в системі “дорослий-дитина” спричиняє у дітей раннього віку внутрішній дискомфорт у вигляді тривог і страхів. Дослідження А. Прихожан (1990), О. Смирнової (1995), Й. Лангмейєра (1994) та ін. доводять, що умови в будинках дитини є несприятливими для формування близьких емоційних зв'язків. Водночас наявність стійкого емоційного зв'язку дитини з близьким дорослим, який Дж. Боулбі (1982) визначав як надійну прихильність, є основою для всього іiі подальшого розвитку. Дефіцит спілкування з близьким дорослим та недостатня кількість емоційних контактів призводять до серйозного дистресу, виникнення проблем, пов'язаних із психічним розвитком і поведінкою дитини (Раттер, 1987). Тому усиновлювачі, які беруть на виховання дитину-сироту або дитину, позбавлену батьківського піклування, мають знати, як правильно реагувати на іiі негативну поведінку, зумовлену материнською депривацією, знати про свої слабкі і сильні сторони та бути гнучкими в підходах до виховання. Аналіз досліджень К. Бєлогай, I. Морозової, Т. Отт (2014), присвячених проблемам, які виникають у прийомних сім'ях, показує, що прийомні батьки: 1) не знають особливостей психологічного розвитку дітей, які мали негативний досвід проживання в біологічній сім’і; 2) не готові до труднощів і змін у сімейних стосунках, які виникають 3 появою нового члена сім'і; 3) не мають знань 
медичного характеру про розвиток дітей; 4) конфліктують 3 кревними дітьми або/і близькими родичами через прийомну дитину; 5) не вміють адекватно реагувати на невротичні реакції прийомної дитини, не знають, як відучити іiї від шкідливих звичок, як допомогти подолати конфлікти 3 однокласниками, вчителями, покращити шкільну успішність, як запобігти немотивованим утечам з дому. Очевидно, що з такими проблемами стикаються і сім'ї усиновлювачів, хоч через таємницю усиновлення і відсутність психологічного супроводу достовірної статистики щодо цього немає.

Батьківство починає розвиватися в людині з моменту ії народження, коли вона фіксує образ своїх батьків та ідентифікує себе з ними, а потім на практиці коригує (або не коригує) свої дії в ролі матері/батька і власні уявлення про себе як батьківську фігуру (Боулби, 2003; Фрейд, 1997; Kaes, 1993; Roussillon, 2007). Наша гіпотеза полягає в тому, що взаємодія 3 дітьми не завжди відбувається відповідно до їхніх потреб - часто виховання дитини будується на інтроєктах і настановленнях, які були задані батьківськими фігурами самих усиновлювачів. Тому ми вважаємо, що психологічна робота з батьківськими его-станами усиновлювачів та їхніми несвідомими настановленнями, сценарними посланнями допоможе налагодити контакт з усиновленими дітьми і позитивно вплине на розв'язання складних соціальних ситуацій.

Дослідження складних соціальних ситуацій у сім'ях усиновлювачів та їх опрацювання здійснювалося впродовж 2017-2020 років. Для вивчення соціально-психологічних факторів, які впливають на виникнення складних соціальних ситуацій у родинах усиновлювачів, було використано напівструктуроване інтерв'ю, що проводилося на базі Київського міського будинку дитини в м. Ворзелі, та включене спостереження (86 годин) у групі взаємопідтримки для усиновлювачів на базі студії особистісного розвитку в м. Києві. У дослідженні взяли учать 50 осіб віком від 27 до 50 років, із них 15 осіб, крім участі в інтерв'юванні, також відвідували групу взаємопідтримки.

Для психологічної роботи з усиновлювачами використовувалися методи і техніки транзактного аналізу: “батьківське інтерв”ю” (McNeel, 1976) - методика, спрямована на терапію батьківської его-структури клієнта; терапія перерішення (Р. Гулдинг, \& М. Гулдинг, 1997) - робота з клієнтом, завдяки якій він стає суб'єктом нового рішення та монодрами: техніка “порожнього стільця”, обмін ролями, техніка монологу, діалог, інтерв”ю, дублювання, реперентинг (Горностай, 2018).

До складних соціальних ситуацій усиновлювачів ми відносимо конфлікти батьків 3 адміністрацією шкіл, дитячих садків, іншими батьками через негативну поведінку усиновленої дитини щодо одногрупників та вихователів у дитячому садку, щодо однокласників та вчителів у школі. У таких випадках усиновлювачів часто викликають до школи або дитячого садка, щоб висловити їм скарги, негативні оцінки щодо дитини, i врешті-решт просять перевести іiі на домашнє навчання або зовсім забрати з дитячого садка.

Результати проведеної роботи 3 усиновлювачами показали, що існує низка особливостей майбутніх батьків, у яких зазвичай виникають складні соціальні ситуації:

- Усиновлювачі, у яких рідні батьки мали конфліктний характер стосунків. Вони виявляють високі показники міжособової сензитивності, тривожності та інтенсивності дистресу, що переживається. Неусвідомлені батьківські заборони та мінісценарії усиновлювачів (Berne, 1964) зазвичай спрямовуються на усиновлених дітей, що призводить до порушення або погіршення їхньої поведінки.

- Стосунки подружньої пари обтяжені невирішеними проблемами. Результати нашого дослідження довели, що гармонійні стосунки в сімейній парі $\epsilon$ ресурсом для усиновителів у складні періоди взаємодії з дітьми, а в дисфункціональній родині поява труднощів лише загострює негативний психологічний стан батьків, через що поведінка дітей погіршується. Тому від конструктивності подружніх стосунків залежить, як буде відбуватися процес адаптації та проживання травматичного досвіду дитини в сім'ї.

- Мотивація подружжя до прийняття дитини в сім'ю має певну специфіку. Так, до неконструктивної мотивації усиновлювачів Т. Мельничук і Г. Бевз (2016) відносять: 
зменшення душевного болю від втрати кревної дитини, збереження порушених подружніх стосунків, психологічний тиск рідні на подружжя на предмет появи дитини в сім’і, бажання уникнути самотньої старості. Ці мотивації батьків спрямовані на розв'язання їхніх власних психологічних проблем та потреб, а не на допомогу дитині. Тому часто усиновлені діти таких батьків застрягають у своїх переживаннях, що проявляється в порушенні поведінки, формуванні або загостренні невротичних проявів.

- Майбутні батьки мають певні індивідуальні особливості: високий рівень тривожності, низьку стресостійкість тощо. У батьків з високим рівнем тривожності і низьким рівнем стресостійкості виникає зазвичай більше труднощів з вихованням дітей, особливо тих, які мали негативний досвід проживання в сім’і і в яких збереглися про це неприємні спогади, або дітей, які зазнали насильства.

- Нездатність батьків оцінити свої слабкі та сильні сторони як вихователів дитинисироти або дитини, позбавленої батьківського піклування, яку пропонують усиновити/удочерити. Психологічні травми, які діти отримали внаслідок материнської депривації або жорстокого поводження в біологічній сім'ї, негативно впливають на формування життєвої позиції та сценарію, що проявляється насамперед у порушенні їхньої емоційної сфери та поведінки

- Батьки не знають особливостей вікового і психологічного розвитку дітей. Часто усиновлювачі не помічають порушень у психологічному розвитку дітей, а порушення в поведінці списують на “поганий характер" і не звертаються за консультацією до дитячого психіатра або невролога. Несвоєчасне звернення по допомогу в разі затримки психологічного розвитку або психічних порушень призводить до виникнення складних соціальних ситуацій, які можна було б мінімізувати.

Складні соціальні ситуації в сім'ях усиновлювачів зазвичай виникають через негативну поведінку усиновлених дітей. Ідеться про часту протестну поведінку, негативізм, обман, агресію щодо інших дітей і дорослих, крадіжки, втечі з дому. Як правило, причиною такої поведінки усиновленої дитини є непрожитий травматичний досвід, негативні сценарні послання, які вона отримала внаслідок материнської депривації або насильства в біологічній сім’ї. Сила травматизації дитини залежить від багатьох факторів: iï власного сприйняття того, що відбувається в навколишньому світі; особливостей їі емоційної сфери (Стюарт, \& Джойнс, 2002); кількості втрат; часу, проведеного в біологічній сім'ї або інтернатній установі. Кожен випадок аналізується індивідуально, з урахуванням вищезазначених умов розвитку.

Підсумовуючи, звернімося до теорії К. Роджерса (2001), який вважав, що людині від природи властива тенденція до зростання та розвитку і все, що потрібно для цього, - лише створити відповідні умови. Сформулюємо відповідно до цієї теорії припущення: виховання дитини, яка пережила травматичний досвід, буде відбуватися більш гармонійно і вона може “зцілитися”, якщо усиновлювачі будуть взаємодіяти з дитиною відповідно до ії потреб, приймаючи ії особистість безумовно та безоцінно. Вважаємо, що це можливо лише за умови розуміння i пропрацювання усиновлювачами власних травм, батьківських заборон, сценарних послань та неконстуктивної життєвої позиції.

Для опрацювання складних соціальних ситуацій усиновлювачів ми обрали групову психологічну роботу. Переваги групової роботи досить вичерпно описав К. Рудестам (1999). Він стверджує, що груповий досвід протидіє відчуженню; у групі можна простежити відтворення системи стосунків, характерних для реального життя учасників групи; група надає можливість отримувати зворотний зв'язок і підтримку від людей зі схожими проблемами; у групі людина може навчатися поводитися інакше, ніж завжди, сформувати нові моделі поведінки, навчитися по-новому ставитися до себе й людей; взаємодія в групі створює напруженість, яка допомагає з'ясувати психологічні проблеми кожного; групова форма $\epsilon$ прийнятнішою і з економічного погляду: для учасників робота в тренінговій групі дешевша, ніж індивідуальна терапія (i для багатьох тренінгова робота набагато ефективніша). 
Наша психологічна робота в групі поєднувала як групові, так і індивідуальні методи роботи. Ми працювали в групі як окремо 3 кожним учасником, концентруючись на внутрішньопсихічному пізнанні (взаємодії між його его-станами: батьківський его-стан, дитячий і дорослий - усередині усиновлювача), так і приділяли увагу груповій динаміці взаємодії між членами групи.

Аналіз психологічної роботи з усиновлювачами показав, що на процес переживання складних соціальних ситуацій та стосунки 3 дітьми безпосередньо впливає власний досвід усиновлення, отриманий у батьківській сім’і. Більшість усиновлювачів приходить на психологічну групу взаємопідтримки з історією травматичного досвіду, який вони отримали у своїй першій і найбільш важливій групі - у батьківській сім’ї. Оскільки психологічна група має схожість із сім'єю в багатьох аспектах (Ялом, 2007), усиновлювачі взаємодіяли 3 ведучим групи (психологом) та іншими учасниками так, як вони взаємодіяли зі своїми батьками та усиновленими дітьми. Це давало більше можливостей для аналізу складних соціальних ситуацій, у яких опинилися сім'ї, та психологічної допомоги усиновлювачам.

Проживання складних соціальних ситуацій усиновлювачами супроводжується негативними переживаннями і думками, конфліктами в сім'ї та непорозуміннями 3 працівниками закладів, які відвідують діти. Батьки, які опинилися в такій ситуації, думають, що вони зробили помилку, усиновивши дитину, що вони зіпсували собі життя, що дитина в майбутньому може стати злочинцем або нашкодити самим батькам чи іншим людям, 3'являється бажання розусиновити/розудочерити дитину. Усиновлювачі відчувають свою безпомічність, розчарування в собі як у вихователях і в дитині, розпач, відчай, сором через свої негативні думки, страх засудження соціумом, злість на себе і злість на дитину, провину перед чоловіком або дружиною, якщо хтось із них був ініціатором усиновлення, відчуття відторгнення. Такі переживання усиновлювачів лише погіршують або розривають контакт 3 дитиною, i, відповідно, погіршується ії поведінка. Для того щоб вирішити складну соціальну ситуацію, необхідно відновити позитивний контакт усиновлювачів і дитини. Це відбувається поступово, у міру зростання психологічної готовності батьків і за наявності позитивної групової динаміки. На початку роботи групи усиновлювачі самостійно вирішували, хто готовий індивідуально працювати зі своїм випадком.

Для того щоб усиновлювачі перейшли від бажання змінити дитину до бажання відчути іï потреби і працювати зі своїми негативними настановленнями та реакціями, необхідно створити особливий мікроклімат у групі - емпатії, конгруентності та безумовного прийняття. Опитування усиновлювачів, завдяки якому вони змогли відкритися і почати працювати зі своїми страхами і травмами, дало змогу визначити такі чинники:

1. Надія та віра в покращення ситуації або конструктивне розв'язання проблем у взаємодії з усиновленими дітьми.

2. Усвідомлення того, що не у них одних виникають труднощі з усиновленими дітьми і з цим можна справлятися. Позитивний досвід інших учасників.

3. Емоційна підтримка та відсутність засудження з боку групи і ведучого.

Останній феномен особливо важливий, оскільки в нашому суспільстві усиновлення надто міфологізується і прирівнюється до подвигу. Тому зізнатися у своїх негативних емоціях щодо усиновленої дитини особливо важко, а ще тяжче стикатися із засудженням соціуму, особливо коли негативна поведінка дітей призводить до наполегливих прохань 3 боку адміністрації шкіл або дитячих садків забрати дитину на домашнє навчання.

На психологічну роботу усиновлювачів у групі негативно впливало озвучення учасниками історій, коли у дітей попри психологічну роботу зберігалися певні неконструктивні патерни поведінки. (Наприклад, коли батьки, які усиновили дитину пів року назад, чули про те, що ті, які усиновили п’ять років назад, усе ще мають проблеми). Деякі учасники проєкували цей досвід на себе, і мотивація продовжувати відвідувати групу падала. Цей момент потрібно обов'язково відстежувати і винести його на обговорення: слід підтримати учасника, повернути йому віру в те, що його ситуація не безнадійна, розвіяти міф про фатальність ситуації. 
Психологічна робота в групі з усиновлювачами проводиться на кількох рівнях:

- емоційному (отримання підтримки; переживання прийняття себе групою; усвідомлення власних емоцій, реакцій; проговорення, прийняття та вираження почуттів);

- когнітивному (усвідомлення зв'язку своїх витіснених, невирішених психологічних проблем із власними батьківськими фігурами та впливу проблем на стосунки з усиновленою дитиною). На цьому етапі починається відновлення емоційного контакту з дитиною; дитини).

- поведінковому (формування нових стратегій поведінки відповідно до потреб

Після того як у групі встановлено стосунки, які базуються на довірі учасників, а усиновлювачі відчувають прийняття і відсутність будь-якого засудження, можна починати безпосередню роботу з окремими випадками усиновлювачів. На початку психологічної роботи ведучий повідомляє, як буде проходити робота групи, та ознайомлює учасників 3 теорією, яка лежить в основі групової роботи.

Робота зі сценарними рішеннями усиновлювачів спиралася як на діагностичну (виявлення заборон і сценарних рішень, видів драйверів), так і на консультативну (рольове моделювання нових поведінкових моделей виходу із сценарію) модель.

Результати психологічної роботи 3 усиновлювачами показали, що особливо ефективним методом роботи в групі $\epsilon$ монодрама. Вона має як терапевтичну, так i діагностичну цінність. Монодрама усиновлювачів проводилася під час роботи групи на запит учасників, які хотіли розібрати свою проблемну ситуацію; інші учасники спостерігали і в кінці роботи ділилися своїми переживаннями, давали зворотний зв'язок. Аналіз зворотного зв'язку усиновлювачів показав ще один зцілювальний ефект у груповій роботі, оскільки учасники, які були в ролі клієнтів, отримували щирий емоційний відгук на свої проблемні ситуації, а для інших учасників це була можливість для занурення в себе і саморефлексії.

Як правило, для першої монодрами використовувалася техніка “діалог” 3 усиновленою дитиною. Усиновлювач пересідав на порожній стілець, перебираючи на себе роль усиновленої дитини, "яка сиділа" на цьому стільці, а на попередньому місці ніби продовжував “сидіти” уявний усиновлювач. Діалог усиновлювача 3 дитиною відбувався 3 поперемінним обміном ролями з нею. Психолог дублював репліки усиновлювача і дитини, почергово сідаючи то на один, то на другий (порожній) стілець. Таким чином, завдяки передаванню психологом інтонацій та невербальних проявів усиновлювач міг простежити найтонші нюанси, які ним не усвідомлювались, не сприймалися напряму або заперечувалися. Діалог виконував низку терапевтичних завдань. Усиновлювачі могли виразити свої почуття і тривоги, задати питання, які їх турбували, і мали можливість отримати досвід переживання в ролі дитини, де вони зазвичай знаходили приховані до цього часу мотиви негативної поведінки, страхи та інші регулятори вчинків, які нещодавно інтерпретували зовсім поіншому, інколи - $з$ точністю до навпаки. Ця техніка є першим етапом на шляху до побудови якісно нового контакту з дитиною.

Аналіз відповідей усиновлених дітей під час роботи з технікою “діалог” показав, що зазвичай усиновлені діти почуваються поганими, неповноцінними, відчувають недовіру до усиновлювачів, страх, що від них відмовляться знову, бояться, що їх знову зрадять. Зі свого боку, усиновлювачі бачать себе очима дитини, яка зчитує всі невербальні нюанси та інтонації, які в реальному житті виражають батьки. Завдяки роботі з технікою “діалог” усиновлювачі починають розуміти, що відчуває їхня дитина, чому вона може проявляти негативні патерни поведінки і як усиновлена дитина може інтерпретувати слова та поведінку усиновлювачів. На зміну бажанню “переробити” дитину приходить бажання їй допомогти.

Під час індивідуальної психологічної роботи в групі 3 усиновлювачами нам доводиться стикатися 3 певною їх ретравматизацією. Виявилося, що зазвичай усиновлена дитина має такі самі переживання, які усиновлювачі відчували в дитинстві, а їхні батьки, як тепер вони, не могли контейнерувати ці переживання, боялися зіткнутися зі своїм власним болем. Батьки часто переживають не вирішену в дитинстві потребу в безумовній любові, несвідомо очікуючи отримати таку любов від усиновленої дитини. Негативна поведінка 
дитини сприймається як відторгнення і відбувається ретравматизація усиновлювачів. Тоді необхідна психологічна робота усиновлювачів 3 їхньою дитячою та батьківською егоструктурою.

Для того щоб складні соціальні ситуації в сім'ях усиновлювачів вирішувалися позитивно, важливо, щоб взаємодія з усиновленою дитиною відбувалася на основі дорослоїего структури (рис.).

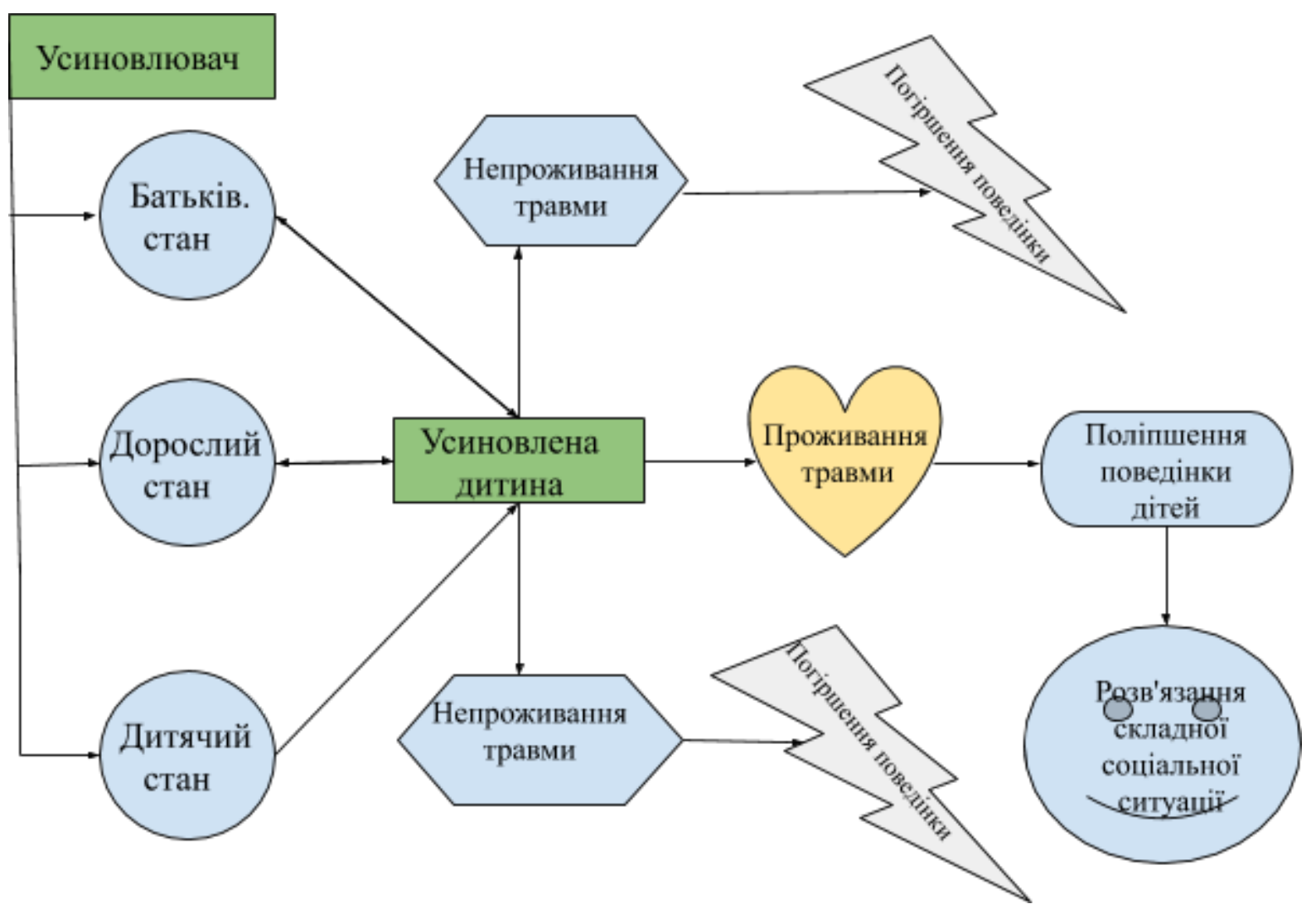

Рис. Транзакційна схема взаємодії усиновлювачів $з$ дитиною

Ефективна взаємодія усиновлювачів з дитиною в сім’ї як малій групі спрямована на зміну іiі негативної поведінки шляхом “проживання травматичного досвіду” і відновлення базової довіри. У процесі психологічної роботи усиновлювачі змінюють своє ставлення до негативних патернів поведінки дітей, зумовленої передусім їхнім раннім травматичним досвідом, і починають проговорювати дитині іiі емоції та почуття, тим самим показуючи, що приймають i розуміють дитину. Після опрацювання власних психологічних травм усиновлювачі переставали боялися говорити 3 дитиною про іiі травматичний досвід, згадувати про біологічну родину дитини і проговорювати ії почуття, пов'язані з цією родиною. Це позитивно впливало на поведінку дітей, у стосунках почало з'являтися більше позитивних моментів. Діти стали більш відкритими, могли говорити і згадувати біологічних батьків, задавати питання, чому так сталося, що вони не з ними, згадувати уривки із свого життя. На цьому етапі позитивно зарекомендували себе ігри батьків і дітей з регресією, коли діти могли грати роль немовляти, а усиновлювачі їх няньчили і колисали, “годували" 3 пляшечки.

Аналіз результатів психологічної роботи в групі з усиновлювачами показав, що пропрацювання проблемних зон у стосунках з власними батьками позитивно впливає не тільки на стосунки з усиновленими дітьми, а й на подружні стосунки. Жінки, які брали участь у роботі групи, скаржилися на те, що чоловіки часто дистанціювалися від проблем, які виникали в сім’ї з усиновленими дітьми, “йшли” в роботу, не допомагали вирішувати проблемні ситуації. У таких сім'ях напруженість між подружжям наростала і поведінка дітей 
ставала ще гіршою. Серед жінок було дві категорії: ті, хто хотів допомоги й ображався, коли iï не отримував, i ті, хто, “оберігав” чоловіка від проблем. Під час роботи групи ці ситуації пропрацьовувалися, жінки могли відреагувати - виплеснути свою злість, образи, страх - i віддати частину відповідальності чоловіку. Під час психологічної роботи з усиновлювачами ми зауважили, що коли в батьківських сім'ях усиновлювачів-чоловіків були емоційно холодна, авторитарна мати i батько, який дистанціювався від виховання, то в разі усиновлення хлопчика стосунки подружжя погіршувалися, оскільки чоловік несвідомо асоціював себе з дитиною і проєкував образ матері на дружину. У таких сім'ях було важко домовитися про правила і єдину стратегію виховання дитини, оскільки обмеження i встановлення меж, які пропонувала дружина, сприймалися чоловіком як “травмування" дитини. Жінки-усиновлювачі, які виховувалися в сім'ях 3 безініціативним батьком, недооцінювали можливості чоловіка і брали всю відповідальність за виховання на себе, що призводило до втрати ресурсу і хронічної втоми жінки. Робота усиновлювачів зі своєю “внутрішньою дитиною” допомогла їм у ставленні до усиновленої дитини більше утримуватися в его-стані Дорослого, завдяки чому усиновлені діти могли проживати свою травму. Усиновлювачі були переорієнтовані насамперед на потреби дитини й змогли усвідомити, які саме їхні реакції та поведінка були зумовлені власним травматичним досвідом.

Налагодження контакту з дітьми сприяло вирішенню складних соціальних ситуацій: діти, які крали, припиняли це робити або крадіжки ставали здебільшого ситуативними; діти поверталися до навчальних закладів, поведінка в колективі значно покращувалася; діти ставали більш відкритими, менше обманювали. Водночас розв'язання складних соціальних ситуацій у сім'ях усиновлювачів - це тривалий процес. Можливі відкати назад: повторення у дітей негативних форм поведінки або виникнення нових, яких раніше не було. Тому групова підтримка є особливо важливою.

Якщо в перші роки групової психологічної роботи усиновлювачі були більше зосереджені на вирішенні своїх проблемних ситуацій, то на третьому році учасники групи почали виконувати роль терапевта один для одного, озвучували глибокий зворотний зв'язок та надавали іншим учасникам емоційну підтримку. Усиновлювачі опанували навички саморефлексії, почали самостійно аналізувати причини негативної поведінки дітей, зумовлені їхнім минулим травматичним досвідом, та навчилися відкрито говорити про свої переживання. Батьки відмічали, що це допомогло їм налагодити більш тісний емоційний контакт 3 дітьми, що позитивно вплинуло на їхню поведінку: стало менше істерик, негативізму, агресії щодо батьків та оточення. Батьки почали цікавитись особливостями виховання дітей з порушенням прихильності, дехто з усиновлювачів (10\%) виявив готовність до ще одного всиновлення, а понад дві третини учасників (70\%) висловили бажання і далі брати участь у роботі групи.

Про ефективність психологічної роботи в групі усиновлювачі говорили, зокрема, таке: “є розуміння, що я не одна і як із цим справлятися”, “з'явилося розуміння причин негативної поведінки дитини”, “зустрічі дуже допомагають зрозуміти, куди мені рухатися”, “група - це місце, де можна перевести подих, розрядитися і зрозуміти, що відбувається”. Аналіз зворотного зв'язку усиновлювачів свідчить про необхідність створення таких груп взаємодопомоги при всіх соціальних службах для дітей і молоді в кожному місті України. Результати психологічної роботи показують, що відкритість усиновлювачів щодо обговорення питань народження дитини, проблем перебування іï в біологічній сім'ї покращує психологічний клімат у родині. Психологічна робота усиновлювачів над батьківською і дитячою его-структурою методами транзактного аналізу та монодрами допомагає їм прожити власні дитячі травми, налагодити близькі стосунки 3 дитиною, конструктивно вирішувати складні соціальні ситуації.

У процесі роботи над складними соціальними ситуаціями, які виникали в сім'ях усиновлювачів, ми зауважили недостатній рівень просвітницької діяльності щодо психологічних особливостей дітей, позбавлених батьківського піклування, як серед 
адміністрації, так і серед вихователів та вчителів закладів освіти. Таємниця усиновлення, відсутність соціально-психологічного супроводу призводять до того, що в разі виникнення складних соціальних ситуацій сім’ї усиновлювачів залишаються сам на сам зі своїми проблемами.

Досвід роботи з усиновлювачами показав, що вони стикаються із серйозними наслідками материнської депривації в усиновлених дітей. Без психологічної оцінки усиновлювачів та соціально-психологічного взаємодобору немає гарантії, що усиновлювачі в разі виникнення проблем самостійно звернуться по допомогу. Майже всі усиновлювачі 3 неконструктивною мотивацією не були готові до психологічної роботи в групі взаємопідтримки та залишали іiі. Це підвищує ризики дисфункції сім’ї та дезадаптації усиновленої дитини, жорстокого поводження усиновлювачів з дітьми або повернення дітей до інтернатного закладу. Тому важливо звернути увагу на удосконалення процесу підготовки до усиновлення.

Висновки та перспективи подальших досліджень. Отже, визначено низку психологічних та соціально-психологічних особливостей усиновлювачів, які проживають складні соціальні ситуації: вони досі потерпають від власної дитячої травми, яка нерідко має гендерну специфіку і проєкується на дитину своєї статі, зумовлюючи подружні конфлікти та дисфункцію сім'ї; рідні батьки усиновлювачів мали конфліктний характер стосунків; неконструктивна мотивація до усиновлення; неспроможність усиновлювачів оцінити свої слабкі і сильні сторони у вихованні дитини-сироти або дитини, позбавленої батьківського піклування, яку вони хочуть усиновити.

Результати опрацювання складних соціальних ситуацій з усиновлювачами в групі психологічної взаємодопомоги довели ефективність групової психологічної роботи. Визначено низку групових механізмів, які позитивно впливають на вирішення проблемних ситуацій усиновлювачів:

1) фасилітація взаємодії - сприяє проявам емоційної підтримки, зняттю напруженості та засвоєнню батьками нових моделей поведінки в малій групі;

2) спонтанна наративізація в групі індивідуальних історій - полегшує долання групових (сімейних і соціальних) міфів про усиновлення як подвиг або ж початкову негативну фатальність ситуації усиновлення;

3) генераційна і трансгенераційна передача досвіду долання психологічних травм у малій групі - оскільки попередні неопрацьовані сімейні травми батьків-усиновлювачів актуалізуються в новій ситуації, яка має ознаки соціальної значущості та психологічної напруженості, рефлексія та опрацювання усиновлювачами батьківських сценаріїв, заборон та негативних послань сприяє доланню складних життєвих і соціальних ситуацій у сім’ї.

Тривала робота в групі психологічної підтримки батьків-усиновлювачів сприяє виникненню групової динаміки та формуванню феномену “група як ціле”. По суті, взаємодія в групі є моделлю взаємодії в сім'ях усиновлювачів як реальних малих групах. Встановлення довіри у взаємодії в групі психологічної взаємопідтримки сприяє розв'язанню ключової проблеми - подоланню відчуття відчуженості усиновлювачів у соціумі. Формат групової психологічної роботи дає змогу працювати індивідуально, з кожним усиновлювачем окремо, при цьому усиновлювач дістає підтримку від учасників групи. При цьому вартість групової роботи $€$ значно нижчою порівняно 3 вартістю індивідуального консультування, що підтримує економіку сім’ї, яка проживає складні соціальні ситуації.

Перспективами подальшого дослідження $є$ корекція негативного життєвого сценарію усиновлених дітей шляхом групової психологічної роботи з ними (починаючи 3 молодшого шкільного віку і до підліткового). Дитина приходить у сім'ю усиновлювачів уже з певними життєвими сценаріями. Тому усиновлювачі не завжди можуть допомогти дитині подолати психологічні проблеми самостійно, часто вони стикаються 3 негативною проєкцією i незаслуженим обезцінюванням та недовірою з її боку. Вважаємо, що виявлення негативних сценарних рішень і настановлень усиновлених дітей та їх “перевирішення” позитивно вплине 
на майбутнє дітей, значно зменшать ризики повернення їх до інтернатних закладів, появи у них делінквентної та девіантної поведінки, дисфункції сім’ї усиновлювачів.

\section{Список використаних джерел}

Бардышевская, М. (2006). Развитие привязанности у эмоционально депривированных детей. Дефектология, 1, 6-20.

Бев3, Г. (2015). Вікова динаміка семантики уявлень дорослих про дітей та практика замінного догляду за дітьми. Актуальні проблеми психології, 12, 10-17.

Бевз, Г., \& Мельничук, Т. (2016). Мотивація до усиновлення і прийомного батьківства як чинник прогностики їх успішності. Актуальні проблеми психологї, 1(44), 53-57.

Боулби, Д. (2003). Привязанность. Москва: Гардарики.

Винникотт, Д. (2004). Мать и дитя. Екатеринбург: Литур.

Горностай, П. (2018). Консультативная психология. Теория и практика проблемного подхода. Киев: Ника-Центр.

Гошовський, Я. (2017). Специфіка самоідентичності депривованих підлітків: ревіталізаційний ракурс. Причорноморські психологічні студї, 1, 24-28.

Гулдинг, М., \& Гулдинг, Р. (1997). Психотерапия нового решения. Теория и практика. Москва: Независимая фирма "Класс".

Демірджі, Т. (2016). Розвиток ідентичності дитини в умовах прийомної сім'ї (Дис. канд. психол. наук). Державний заклад вищої освіти "Університет менеджменту освіти" Національної академії педагогічних наук України, Київ.

Иванкова, Н., Повстян, Л., \& Арсентьева, Е. (2017). Психолого-педагогические предпосылки развития личности воспитанников детского дома. Вестник психологии и педагогики Алтайского государственного университета, 4, 80-89.

Кремнева, Л., Проселкова, М., Козловская, Г., \& Иванов, М. (2017). К вопросу об этиологии сиротства. Социальная и клиническая психиатрия, 1(27), 20-25.

Лахвич, Ю., \& Головнева, О. (2017). Опыт усыновителей в воспитании биологического ребёнка - ресурс или риск в процессе адаптации? Адукаџыл і выхаванне, 11, 137-44.

Майн, Н. (2014). Образы родителей у потенциальных усыновителей: эмпирическое исследование. Вестник Костромского государственного университета. Серия: Педагогика. Психология. Социокинетика, 20(3), 169-174.

Мельничук, Т. (2013). Визначення індикаторів психологічної готовності до усиновлення. Наукові записки Національного університету “Острозька академія”. Психологія і педагогіка, 22, $116-122$.

Морозова, І., Белогай, Т., \& Отт О. (2014). Особенности детско-родительских отношений в приемных семьях. Вестник Кемеровского государственного университета, 3(59), 146-151.

Пєша, I. (2003). Дитячий будинок сімейного типу як особлива форма влаштування дітей сиріт. Украӥнський соиіум, 1(2), 72-80. Питер.

Прихожан, А. \& Толстых, Н. (2007). Психология сиротства. (3-е изд.). Санкт- Петербург:

Раттер, М. (1987). Помощь трудным детям. Москва: Прогресс.

Роджерс, К. (2001). Становление личности. Москва: Эксмо-пресс.

Рудестам, К. (1999). Групповая психотерапия. Санкт-Петербург: Питер

Стюарт, Й., \& Джойнс, В. (2002). Основи ТА: транзакиійний аналіз. Київ: ФАДА, ЛТД.

Удовенко, Ю. (2007). Вплив несприятливих умов соиіалізацї̈ на психічний розвиток дитини (Дис. канд. психол. наук). Київський національний університет імені Тараса Шевченка, Київ.

Фрейд, 3. (1997). Я и Оно. Очерки по психологии сексуальности (с. 472-477). Минск: Попурри.

Шпиц, Р. (2001). Психоанализ раннего детского возраста. Москва: ПЕР СЭ; СанктПетербург: Университетская книга.

Эриксон, Э. (2000). Детство и общество. (2-е изд.). Санкт-Петербург: Летний сад. 
Ялом, И. (2007). Групповая психотерапия. Теория и практика. (2nd ed.). Москва: Апрель Пресс, Психотерапия. Press.

Berne, E. (1964). Games People Play: The Psychology of Human Relationships. New York, Grove

Geissmann, C., \& Houzel D. (Eds.) (2000). L'enfant, ses parentset le psychanalyste. La capacité à être mère (pp. 219-229). Paris: Bayard Editions.

Kaes, R. (1993). Transmission de la vie psychique entre générations. Paris: Dunod

McNeel, J. (1976). The Parent Interview. Transactional Analysis Journal, 6(1), 61-68. Masson.

Roussillon, R. (2007). Manuel de psychologie et de psychopathologie clinique générale. Paris:

\section{References}

Bardyshevskaya, M. (2006). Razvitiye privyazannosti u emotsionalno deprivirovannykh detey [The development of attachment in emotionally deprived children]. Defektologiya, 1, 6-20. (in Russian)

Berne, E. (1964). Games People Play: The Psychology of Human Relationships. New York, Grove Press. (in English)

Bevz, H. (2015). Vikova dynamika semantyky uiavlen doroslykh pro ditei ta praktyka zaminnoho dohliadu za ditmy [Age dynamics of semantics of adults ideas about children and the practice of substitute child care]. Aktualni problemy psykholohii, 12, 10-17. (in Ukrainian)

Bevz, H., \& Melnychuk, T. (2016). Motyvatsyia do usynovlennia i pryiomnoho batkivstva yak chynnyk prohnostyky yikh uspishnosti [Motivation for adoption and foster care as a factor in predicting their success]. Aktualni problemy psykholohii, 1(44), 53-57. (in Ukrainian)

Boulbi, D. (2003). Privyazannost [Affection]. Moscow: Gardariki. (in Russian)

Demirdzhi, T. (2016). Rozvytok identychnosti dytyny v umovakh pryiomnoi simi [Development of the child's identity in the conditions of a foster family] (Dissertation of the Ph. D. Thesis Candidate of Psychological Sciences). Derzhavnyi zaklad vyshchoi osvity "Universytet menedzhmentu osvity" Natsionalnoi akademii pedahohichnykh nauk Ukrainy, Kyiv. (in Ukrainian)

Erikson, E. (2000). Detstvo i obshchestvo [Childhood and Society] (2nd ed.). St. Petersburg: Letniy sad. (in Russian)

Freud, S. (1997). Ya i Ono. Ocherki po psikhologii seksualnosti [I and It. Essays on the Psychology of Sexuality] (pp. 472-477). Minsk: Popurri. (in Russian)

Geissmann, C., \& Houzel D. (Eds.) (2000). L'enfant, ses parentset le psychanalyste. La capacité à être mère. [The child, his parents and the psychoanalyst. The ability to be a mother] (pp. 219-229). Paris: Bayard Editions. (in French)

Gornostay, P. (2018). Konsultativnaya psikhologiya. Teoriya i praktika problemnogo podkhoda [Counseling psychology. Theory and practice of the problematic approach]. Kyiv: Nika-Tsentr. (in Russian)

Gulding, M., \& Gulding, R. (1997) Psikhoterapiya novogo resheniya. Teoriya i praktika [New Solution Psychotherapy. Theory and practice]. Moscow: Nezavisimaya firma "Klass". (in Russian)

Hoshovskyy, Ya. (2017). Spetsyfika samoidentichnosti depryvovanykh pidlitkiv: revitalizatsiinyi rakurs [Specifics of self-identity of deprived adolescents: revitalization perspective]. Prychornomorski psykholohichni studii, 1, 24-28. (in Ukrainian)

Ivankova, N., Povstyan, L., \& Arsentyeva, Ye. (2017). Psikhologo-pedagogicheskiye predposylki razvitiya lichnosti vospitannikov detskogo doma [Psychological and pedagogical prerequisites for the development of the personality of children in an orphanag]. Vestnik psikhologii i pedagogiki Altayskogo gosudarstvennogo universiteta, 4, 80-89. (in Russian)

Kaes, R. (1993). Transmission de la vie psychique entre générations [Transmission of psychic life between generations]. Paris: Dunod. (in French).

Kremneva, L., Proselkova, M., Kozlovskaya, G., \& Ivanov, M. (2017). K voprosu ob etiologii sirotstva [On the question of the etiology of orphanhood]. Sotsialnaya i klinicheskaya psikhiatriya, 1(27), 20-25. (in Russian) 
Lakhvich, Yu., \& Golovneva, O.(2017). Opyt usynoviteley v vospitanii biologicheskogo rebyonka resurs ili risk v protsesse adaptatsii? [The experience of adoptive parents in raising a biological child - a resource or a risk in the adaptation process?]. Adukatsyya $i$ vykhavanne, 11, 137-44. (in Russian)

Mayn, N. (2014). Obrazy roditeley u potentsialnykh usynoviteley: empiricheskoye issledovaniye [Parent images in prospective adoptive parents: an empirical study]. Vestnik Kostromskogo gosudarstvennogo universiteta. Seriya: Pedagogika. Psikhologiya. Sotsiokinetika, 20(3), 169-174. (in Russian)

McNeel, J. (1976). The Parent Interview. Transactional Analysis Journal, 6(1), 61-68. (in English)

Melnychuk, T. (2013). Vyznachennia indykatoriv psykholohichnoi hotovnosti do usynovlennia [Determination of indicators of psychological readiness for adoption]. Naukovi zapysky Natsionalnoho universytetu "Ostrozka akademiya". Psykholohiia i pedahohika, 22, 116-122. (in Ukrainian)

Morozova, I., Belogay, T., \& Ott O. (2014). Osobennosti detsko-roditelskikh otnosheniy v priyemnykh semyakh [Features of parent-child relationships in foster families]. Vestnik Kemerovskogo gosudarstvennogo universiteta, 3(59), 146-151. (in Russian)

Prikhozhan, A., \& Tolstykh, N. (2007). Psikhologiya sirotstva [The psychology of orphanhood]. (3d ed.). St. Petersburg: Piter. (in Russian)

Pyesha, I. (2003). Dytiachyi budynok simeinoho typu yak osoblyva forma vlashtuvannia ditei syrit [Family-type orphanage as a special form of placement of orphans]. Ukrainskyi sotsium, 1(2), 72-80. (in Ukrainian) Russian)

Ratter, M. (1987). Pomoshch trudnym detyam [Help for difficult children]. Moscow: Progress. (in

Rogers, C. (2001). Stanovleniye lichnosti [Formation of personality]. Moscow: Eksmo-press. (in Russian)

Roussillon, R. (2007). Manuel de psychologie et de psychopathologie clinique générale [Manual of psychology and general clinical psychopathology]. Paris: Masson. (in French)

Russian)

Rudestam, K. (1999). Gruppovaya psikhoterapiya [Group psychotherapy]. St. Petersburg: Piter. (in

Shpits, R. (2001). Psikhoanaliz rannego detskogo vozrasta [Psychoanalysis of early childhood]. Moscow: PER SE; St. Petersburg: Universitetskaya kniga. (in Russian)

Stuart, Y., \& Dzhoyns, V. (2002). Osnovy TA: tranzaktsiinyi analiz [Basics TA transactional analysis]. Kyiv: FADA, LTD. (in Ukrainian)

Udovenko, Yu. (2007). Vplyv nespryiatlyvykh umov sotsializatsii na psykhichnyi rozvytok dytyny [Influence of unfavorable conditions of socialization on mental development of the child] (Dissertation of the $\mathrm{Ph}$. D. Thesis Candidate of Psychological Sciences). Kyivskyi natsionalnyi universytet imeni Tarasa Shevchenka, Kyiv. (in Ukrainian)

Vinnikott, D. (2004). Mat i ditya [Mother and child]. Ekaterinburg: Litur. (in Russian)

Yalom, I. (2007). Gruppovaya psikhoterapiya. Teoriya i praktika [Group psychotherapy. Theory and Practice]. (2nd ed.). Moscow: Aprel Press, Psikhoterapiya. (in Russian) 